\title{
Militant Islam in Southeast Asia: New Insights into Jihads in Indonesia, Malaysia and the Philippines
}

\author{
KIRSTEN E. SCHULZE and JULIE CHERNOV HWANG
}

KIRSTEN E. SCHULZE is an Associate Professor at the London School of Economics, the United Kingdom. Postal address: Department of International History, London School of Economics, Houghton Street, London WC2A 2AE, United Kingdom; e-mail: K.E.Schulze@1se.ac.uk.

JULIE CHERNOV HWANG is an Associate Professor of Political Science and International Relations at Goucher College, Baltimore. Postal address: Goucher College, 1021 Dulaney Valley Road, Baltimore, MD 21204, United States; E-mail: Jchwang@ goucher.edu.

On 22 June 2018, Aman Abdurrahman, the head of the pro-ISIS network Jamaah Ansharud Daulah (JAD), was sentenced to death for his role in inciting terror attacks in Indonesia in 2016 and 2017. ${ }^{1}$ The attacks for which he was found guilty included the January 2016 gun and bomb attack in Jakarta's Thamrin business district and the November 2016 attack on children playing in front of a church in Samarinda, East Kalimantan. ${ }^{2}$ In the first attack, a traffic police post and a branch of Starbucks were targeted, and in the second one a two-year old girl was killed and five other children were injured. Other attacks committed by Islamists affiliated with JAD included the May 2017 Kampung Melayu suicide bombing which killed three police officers, ${ }^{3}$ the June 2017 attack on a police station in North Sumatra which killed one police officer, ${ }^{4}$ and the shooting dead of two police officers in Bima, West Nusa Tenggara, in September $2017 .{ }^{5}$

While Abdurrahman was on trial in the South District court in Jakarta, three churches were simultaneously targeted by suicide bombings in Surabaya on 13 May 2018. ${ }^{6}$ These were carried out by the members of one family comprising husband, wife and four children. Later that day, another family of six was involved in a premature bomb explosion at a house in Sidoarjo (near Surabaya), and the following day, a family of five rode two motorbikes to the entrance of Surabaya police headquarters where they blew themselves up. ${ }^{7}$ All three families were affiliated with JAD. 
Militant Islamism is, of course, not a new phenomenon in Indonesia and Southeast Asia more broadly, where both colonial history and the nature of the post-colonial state have played an important role in the construction of Islamist identities. The origins of militant Islam in contemporary Indonesia, for example, go back to the 1948-65 Darul Islam rebellions, ${ }^{8}$ while the roots of modern Bangsamoro militant Islamism in the Philippines can be found in the 1968 Jabidah massacre. Factionalization has also been a prominent feature of militant Islamist movements in Southeast Asia, often coinciding with political transitions. In the Philippines, the declaration of martial law in 1972 by President Ferdinand Marcos is widely considered as a turning point in the Bangsamoro insurgency for the creation of an Islamic state in the south of the country, which has continued to this day. In Thailand's restive Malay-Muslim majority southern border provinces, a dormant insurgency waged in the name of liberating Patani Darusslam was reignited after Prime Minister Thaksin Shinawatra came to power in 2002. Nevertheless, it was in Indonesia that the rise of militant Islam was most striking.

In Indonesia, the fall of President Suharto in May 1998 allowed for the return of Islamist leaders Abdullah Sungkar and Abu Bakar Ba'asyir who had fled to Malaysia in 1985 where they established Jemaah Islamiyah (JI) in 1993. JI, which drew upon the network of Southeast Asians who had travelled to Afghanistan to fight the Soviet Union after it occupied the country in 1979, or simply to get training and experience, sought to establish an Islamic state in Indonesia. While JI's aim focused on Indonesia, JI developed a transnational structure of four mantiqis (territories) with Mantiqi 1 covering Malaysia and Singapore, Mantiqi 2 covering Indonesia excluding Sulawesi, Mantiqi 3 covering the southern Philippines and Sulawesi, and the final mantiqi covering Australia. A sub-group within JI, associated with Mantiqi 1, mounted a campaign of violence in Indonesia from 1999 to 2003 which included the Christmas 2000 church bombings, the 2002 Bali bombings and the 2003 JW Marriot bombing. That sub-group splintered off in 2005 to form the aspirationally named Al Qaeda in the Malay Archipelago led by Noordin Mohamed Top, and went on to launch the 2005 Bali bombings and the 2009 Marriott and Ritz Carlton bombings. JI also participated in numerous attacks associated with the Poso conflict between 2001 and 2007. ${ }^{9}$ After the 2002 Bali bombings, JI started to lose its transnational structure and fractured due to disagreements over tactics and targets against the backdrop of intensified counterterrorism efforts by the Indonesian security services. ${ }^{10}$

In August 2001, investigations into a failed bombing at a shopping mall in Jakarta also uncovered information on an underground militant group known then as Kumpulan Mujahidin Malaysia (KMM). In a move that has never been satisfactorily explained, the group was later renamed Kumpulan Militan Malaysia by both the Malaysian security agencies and the media. 
KMM proved to be an underground militant Muslim group which sought to overthrow the government of Malaysia and create an Islamic state spanning from the Philippines to Indonesia. KMM was widely believed to have been linked to JI. According to authorities in Singapore, a JI member reportedly assisted the KMM to purchase a boat for activities in Indonesia, while the KMM allegedly aided JI in obtaining ammonium nitrate. ${ }^{11}$ Investigations by Malaysian authorities revealed that the KMM was established on 12 October 1995 by Zainon Ismail and had emerged from Halaqah Pakindo, "a clandestine movement formed in 1986 as an alumni association for Malaysian graduates from religious institutions in Pakistan, India and Indonesia". ${ }^{12}$ There was also a link to the Malaysian Islamist party Parti Islam Se-Malaysia (PAS). Indeed, eight of the ten alleged KMM members detained in an August 2001 raid were members of the PAS youth wing. These included Nik Adli Abdul Aziz, the son of Nik Aziz Nik Mat, the spiritual leader of PAS. Nik Adli was "allegedly elected leader of the KMM at a meeting of 12 senior members in Kampung Seri Aman, Puchong, in early 1999". ${ }^{13}$ However, it was later contended by the Malaysian government that real leadership came from Abu Bakar Ba'asyir and JI's Mantiqi 1 leader Hambali. ${ }^{14}$

In 2007, JI was dealt a severe blow by the police in Poso. This resulted in an internal discussion within the organization which led to JI stepping back from violence in favour of a longer-term educational and dakwah (religious outreach) strategy by 2009. The internal debate also triggered a process of further fragmentation which saw the establishment of Jemaah Ansharut Tauhid (JAT) by Abu Bakar Ba'asyir in 2008. At the same time, Indonesian mujahidin (those engaged in jihad) from various backgrounds moved in to fill the vacuum left by JI with respect to militant jihad and formed an alliance to establish a training camp in Aceh in $2010 .{ }^{15}$ When this camp was broken up by the police, the militants regrouped again, giving rise to Mujahidin Indonesia Timur (MIT) led by Santoso alias Abu Wardah. ${ }^{16}$

Factionalization has also haunted the jihadi movement in the Philippines. The Moro Islamic Liberation Front (MILF) and the Abu Sayyaf Group (ASG) split off from the Moro National Liberation Front (MNLF) in 1984 and 1991, respectively. In 2008, the MILF itself fractured, leading to the emergence of the Bangsamoro Islamic Freedom Fighters (BIFF) under the leadership of Ameril Umbra Kato in 2010. BIFF, like the MILF, has mainly targeted the Armed Forces of the Philippines (AFP), while ASG has a track record for bombings, kidnappings, hostage-taking for ransom and assassinations. In both Indonesia and the southern Philippines, the conflict in Syria and the rise of the Islamic State in Iraq and Syria (ISIS) caused further factionalization of the local jihadi scene resulting in the emergence of new networks 
such as Aman Abdurrahman's JAD as well as some militant groups aligning themselves with ISIS in order to legitimise and strengthen their own local jihadi projects.

\section{Literature Review}

The literature on militant Islam in Southeast Asia has engendered considerable debate on the relationship between local jihadi groups and global jihadi organizations and networks. Two broad schools of thought have emerged, dividing most scholars broadly into "globalists" and "regionalists". The former often come from a terrorism studies or security studies background while the latter are often country specialists or from a regional Islamic studies background. This has resulted in different methodologies and approaches in studying the transnational elements of jihadism — ideological, organizational and financial—and, particularly, how to evaluate them.

The question of the nature of the relationship between local groups and global networks arose when links between JI and al-Qaeda were first revealed. Here the globalists have argued that JI must be seen as a constituent part of al-Qaeda's global Islamist network. The first to advance this argument was Rohan Gunaratna in Inside al-Qaeda: Global Network of Terror, in which he asserted that JI "was formed by Sungkar after meeting Osama [Bin Laden] in Afghanistan", that JI was then "incorporated as an associate group of al-Qaeda", and "over time al-Qaeda gradually absorbed JI into its wider structure". ${ }^{17}$ A similar conclusion was reached by Zachary Abuza in Militant Islam in Southeast Asia: Crucible of Terror, which examined the connections between jihadi groups such as KMM, the MILF, the ASG and above all JI with al-Qaeda. Abuza's analysis revolved around those personalities who had these links such as Riduan Isamudin (alias Hambali) and led him to conclude that JI was "the regional affiliate of al-Qaeda". ${ }^{18}$

Key personalities are also at the heart of Maria Ressa's account of the links between alQaeda and JI in Seeds of Terror: An Eyewitness Account of Al-Qaeda's Newest Center of Operations in Southeast Asia. Ressa also pays particular attention to Hambali-head of Mantiqi 1 (Jemaah Islamiyah's region covering Malaysia and Singapore) and "the highest ranking non-Arab in Al-Qaeda's leadership council”- as well as Omar al-Faruq “Al-Qaeda's senior rep in Southeast Asia" who "was told to move to Indonesia, where he became a sleeper agent, covertly helping Jemaah Islamiyah and other al-Qaeda operatives." 19 Echoing Gunaratna, Ressa states that "Al-Qaeda co-opted the co-founders of Jemaah Islamiyah by providing extensive training and finance" and that JI was Al-Qaeda's network in the region. ${ }^{20}$ Ken Conboy's book, The Second Front: Inside Asia's Most Dangerous Terrorist Network, 
approaches militant Islamism from a globalist perspective as well. ${ }^{21}$ Like Gunaratna, Abuza and Ressa, he points to Hambali's centrality and asserts that "al-Qaeda had grown to see him as a dependable proxy". ${ }^{22}$ However, Conboy stops short of describing JI as a part of al-Qaeda, labelling it instead as an allied jihadist movement. ${ }^{23} \mathrm{He}$ also highlights the divisions within JI regarding the relationship between JI and al-Qaeda, arguing that Hambali and his Mantiqi 1 comrades "were prone to fuse the goals of Jemaah Islamiyah and al-Qaeda. But others, especially in the markaz, sought little or no outside help." 24

These globalists all focus on the transnational elements of militant Islam, which is not surprising as their books were published soon after the 11 September 2001 terrorist attacks in the United States and the 2002 Bali bombings. The transnational elements at that time were the missing puzzle pieces. However, this approach assumed a greater degree of organizational cohesion within JI than actually existed. It also resulted in too much focus on Hambali's Mantiqi 1, and a lack of understanding of the extent to which the links, relationships and opportunities afforded to members of Mantiqi 1 were not applicable to the whole of JI. In addition, this approach neglected the other branches of JI: Mantiqi 2 and Mantiqi 3, which had different leaders, priorities and, importantly, time horizons for the use of violence. Moreover, the focus on the global connections caused them to erroneously conclude that because JI had a transnational structure, its aim was the establishment of "one giant Islamic state". ${ }^{25}$

The globalist approach to the relationship between ISIS in the Middle East and proISIS groups in Southeast Asia mirrored its analysis of JI's relationship with al-Qaeda. Just as al-Qaeda had co-opted and used JI, the ISIS leadership in the Middle East was using pro-ISIS groups in Southeast Asia. In 2016, Gunaratna posited that "ISIS is determined to declare at least one province in Asia in 2016". ${ }^{26}$ A year later, Kumar Ramakrishna asserted that regardless of whether a formal wilayah (province) is declared, ISIS's influence and investment in Southeast Asia were evident. ${ }^{27}$ Reiterating his earlier position, in 2018 Gunaratna claimed that ISIS was "shifting its centre of gravity from Iraq and Syria to its multiple wilayat and divisions in different countries." 28 These, he stated, include the "East Asia Division (mainly Philippines)" which would be used by foreign terrorist fighters "as bases to conduct attacks". ${ }^{29}$ This notion that agency derives from the core is reinforced in the broader literature on ISIS which sees Southeast Asian foreign fighters as so peripheral and inconsequential that it either neglects to mention them at all or does so only in passing. ${ }^{30}$

While globalists have tended to focus on networks and organizational structures-who is connected to whom, and how the money flows - regionalists have tended to approach the question of how to evaluate the transnational elements from the perspectives of motivation, 
historical contextualization, geography and organizational behaviour. For instance, in Riots, Pogroms, Jihad: Religious Violence in Indonesia, John Sidel examines the shift from one form of religious violence in Indonesia to another between 1995 and 2005. Sidel states that "in contrast with the actor-centred accounts of the 'terrorism experts', the stress here is on the powerfully determining effects of historical and sociological contexts". ${ }^{31} \mathrm{JI}$ is thus only one of many actors examined, and it is approached within a broader enquiry into religious violence rather than reduced to its links with al-Qaeda. Similarly, in Solahudin's book The Roots of Terrorism in Indonesia: From Darul Islam to Jema'ah Islamiyah, which examines the evolution of the Indonesian jihadi movement from Darul Islam to Jemaah Islamiyah, the author takes a historical approach, tracing JI's ideological roots back to the Padris in the nineteenth century when the first salafi ideas found their way to the Dutch East Indies. ${ }^{32}$ Solahudin emphasizes the local Indonesian context that shaped the development of the Indonesian jihadi movement in the twentieth century, and above all the internal debates at each critical juncture. It is here that al-Qaeda's relationship with JI fits in, as a relationship with a mere component of JI that was the subject of considerable discussion and criticism within the organization. Likewise, Sidney Jones and Julie Chernov Hwang have shown that rather than being the creation of al-Qaeda, JI is the product of Indonesian history, most notably the 1948-65 Darul Islam rebellions and subsequent suppression of Islamists by President Suharto's New Order regime. ${ }^{33}$ As JI's aims were ultimately about Indonesia, the training of Indonesian jihadis in Afghanistan aimed at strengthening local capacity. Looking at pro-ISIS support in Southeast Asia, Kirsten E. Schulze and Joseph Chinyong Liow in their article on the ISIS phenomenon in Indonesia and Malaysia come to a similar conclusion, arguing that "the potency and appeal of the extremist narrative of ISIS derives from how it animates and feeds off prevailing debates in Indonesia and Malaysia". ${ }^{4}$

For regionalists and area specialists, the starting point has been in Indonesia, Malaysia or the Philippines. They see local dynamics as key to understanding why local jihadi organizations embrace international elements or seek out organizations such as al-Qaeda or ISIS. Not surprisingly, they - as exemplified by the writings of Natasha Hamilton-Hart, John

Sidel, Greg Fealy and Carlyle A. Thayer-have been highly critical of many of the globalists for their oversimplified analytical frameworks, as well as their ignorance of complex local factors. ${ }^{35}$

\section{Militant Islam in Southeast Asia: New Insights into Jihads in Indonesia, Malaysia and the Philippines}


The five articles in this special issue of Contemporary Southeast Asia contribute to this debate on how to evaluate the transnational elements in militant Islam in Southeast Asia by highlighting the importance of the local context for understanding the outbreak of violence and terrorism, support for and recruitment into militancy, and strategic behaviour by jihadi groups. In so doing, they unpack related questions pertaining to the factors that influence and constrain Islamist militant group decision-making, goal attainment and learning.

Julie Chernov Hwang's article examines the factors that prompted JI to move away from terror tactics in favour of a strategy of dakwah (religious outreach) before jihad. It asserts that the devastation by the arrests that followed the 2002 Bali bombings, the splintering off of the pro-bombing wing of JI, and the second series of mass arrests that followed the 2007 police raids on the Tanah Runtuh compound in Poso, Central Sulawesi, caused JI to postpone the use of violence in favour of a strategy of dakwah, education, paramilitary training, recruitment and intensive caderization. This article examines the debates over the conditions under which violence was permissible between Mantiqi 1, on the one hand, and Mantiqi 2, on the other.

Kirsten Schulze's article explores the 1999-2005 Ambon jihad and 2000-07 Poso jihad, asking why the Ambon jihad was characterized by disagreement, infighting, and lack of strategic direction while the Poso jihad was comparatively better led and linked to the broader goals of establishing an Islamic state in Indonesia. The article explores to what extent the better organization of the Poso jihad was the result of lessons learnt from the "mistakes" of the Ambon jihad. It argues that the Ambon jihad was undermined by the lengthy debate within JI, as well as by the shifting dynamics between JI, Mujahidin KOMPAK and Laskar Jihad. It further argues that the Poso jihad was more organized because JI's leadership had a more comprehensive approach to the Poso jihad, because JI and Mujahidin KOMPAK had learnt from the mistakes of the Ambon jihad in the areas of leadership, training, and using local jihads to achieve national aims, and because the intra- and inter-mujahidin dynamics, and with it the "state of jihad", had evolved significantly between February 1999 and September 2000.

Greg Fealy's article looks at apocalyptic literature and jihadism in Indonesia addressing both JI and ISIS supporters in Indonesia. Asking what impact apocalyptic literature has had on the thinking and actions of its Indonesian readers, Fealy analyzes the messaging of Islamic apocalypticism, details the key authors and publishers, and assesses the impact of the apocalyptic narratives on the thinking of different groups within the broader Indonesian jihadi ecosystem. Fealy then moves on to examine the apocalyptic aspects of ISIS's narrative and the role they played in the May 2018 Surabaya bombings. Here he explores the possibility that the 
perpetrators were motivated by a shared conviction that the world was about to end and they would be doomed to hell, if they did not martyr themselves.

Looking at recent dynamics relating to support for ISIS in Malaysia, Joseph Chinyong Liow and Aida Arosaie's article asks why not more Malaysians rushed to heed the ISIS clarion call to fight in either Syria or Iraq. They posit that while ISIS was able to attract some supporters and sympathizers from Malaysia, its recruitment efforts were hampered by effective counterterrorism operations and ISIS's inability to tailor its global narrative to the local Malaysian context. Its silence on the issues of importance to Malay Muslims, notably the Malay dimension of Malay Muslim identity, alienated Malays. Moreover, the Malaysian state had more legitimacy than many of its counterparts in other Muslim nations as the process of Islamization in Malaysia was intertwined with an agenda calling for Malay empowerment. This was reinforced by existing state-sanctioned sectarian and anti-Western narratives that, in turn, limited ISIS's appeal.

In the final article, Quinton Temby looks at the southern Philippines after the siege of Marawi city by pro-ISIS forces in 2017 . Temby examines the trauma experienced by the local population, the role played by foreign fighters in the siege, the impact of the post-Marawi dynamics on the Bangsamoro peace process and the January 2019 Jolo suicide bombing. He argues that the defeat of the pro-ISIS jihadis in Marawi set in motion a shift away from large insurgent groups in Mindanao to smaller, more fragmented groups that are more likely to employ suicide bombings, not just because they see themselves as ideologically aligned with ISIS but also because suicide bombings are the most effective tactical option given their militarily weaker position.

Taken together, these five articles are decidedly "local" in their understanding of how militant groups operate in Southeast Asia, highlighting the unique local contexts and how their ability to be nimble and adaptable within those contexts affects their ability to be successful in recruiting, in spreading their message and in surviving. Moreover, these articles collectively demonstrate that militant Islamist groups behave rationally, respond to opportunities and constraints and learn from their missteps. Chernov Hwang and Schulze address this most directly, with the former highlighting how debates over the use of violence evolved within JI, and the latter underscoring how JI and Mujahidin KOMPAK adapted the lessons of Ambon to Poso. With the exception of Fealy, all of the articles also assess ideology to be far less relevant in understanding Islamist militant group behaviour than globalists would have us expect, and even within Fealy's article, there is considerable intra-group variation in the salience and resonance of Islamic apocalyptical narratives. 
All of the articles employ qualitative methods, including interviews, textual analysis and ethnographic methods to illustrate the rich empirics in each of their chosen cases. The article by Chernov Hwang draws on iterated interviews with 38 members of JI and Tanah Runtuh in the district of Poso, supplemented by texts authored by notable JI leaders and operatives such as Abu Rusydan and Ali Imron, respectively, as well as open source data. Schulze's article is the result of intensive interviews with more than 100 militants and stakeholders in Ambon and Poso. The article by Fealy analyses Islamic texts on eschatology, supplemented by 32 interviews with jihadists, counter-terrorism analysts and Islamic publishers. The article by Temby draws on information gathered from interviews conducted in Mindanao, Cotabato and Zamboanga with former pro-ISIS militants, officials involved in the peace process, NGOs and local residents. The article by Liow and Arosaie uses the genealogical method of ethnographic research as well as discourse analysis to explore Islamist militancy in Malaysia. Overall, these articles paint an empirically robust portrait of Islamist militancy in Southeast Asia.

In conclusion, drawing on deep fieldwork, the articles in this special issue of Contemporary Southeast Asia offer a rich, nuanced portrayal of militant Islamist group decision-making across the themes of recruitment, tactics, strategy and ideology. They collectively highlight the critical salience of local context for understanding the behaviour of Islamist militant groups. One cannot begin to comprehend the Marawi siege without considering the effects of local clan politics. One cannot understand ISIS's lacklustre recruitment in Malaysia devoid of an understanding of the heavy Salafi-inflected political Islam in Malaysia. One cannot accurately assess JI's strategic decision-making without understanding internal debates and cleavages over the use of violence, and one cannot understand JI's comparative success in Poso versus Ambon without understanding the process of political and tactical learning that took place. Finally, even within countries, one should not assume ideological factors held constant across groups; apocalyptical narratives were far more salient among pro-ISIS communities than JI ones. Thus this special issue represents a powerful validation of the local approach and the use of deep fieldwork in research on militant Islamism in Southeast Asia. Moreover, it conveys a clear message to counter-terrorism practitioners that local knowledge and the incorporation of such knowledge in programme design are critical for any modicum of success in countering violent extremism.

\section{NOTES}


Acknowledgements: The authors would like to thank the reviewers for their extremely useful feedback on the various drafts of the articles, the editors of Contemporary Southeast Asia and the LSE Saw Swee Hock Southeast Asia Centre which funded and hosted the workshop on militant Islamism in Southeast Asia in January 2018 which gave rise to this special issue.

1 “JAD Leader Aman Abdurrahman Sentenced to Death", The Jakarta Globe, 22 June 2018, available at https://jakartaglobe.id/context/jad-leader-aman-abdurrahman-sentenced-death; for an analysis of the 2016 Jakarta attack see Kirsten E. Schulze, "The Jakarta Attack: Islamic State's Threat to Indonesia”, CTC Sentinel, Vol 9, issue 1 (January 2016) available at https://ctc.usma.edu/the-jakarta-attack-and-the-islamic-state-threat-to-indonesia/. See also IPAC, "Disunity Among Indonesian ISIS Supporters and the Risk of More Violence", IPAC Report No 25 (February 2016), available at http://www.understandingconflict.org/en/conflict/read/47/Disunity-Among-Indonesian-ISISSupporters-and-the-Risk-of-More-Violence.

2 "Four children injured in suspected militant attack on Indonesia church", Reuters, 13 November 2016 available at https://uk.reuters.com/article/uk-indonesia-security/fourchildren-injured-in-suspected-militant-attack-on-indonesia-church-idUKKBN1380B3.

3 “Suicide Bombers Strike Jakarta, Killing 3 Officers”, The New York Times, 25 May 2017 available https://www.nytimes.com/2017/05/25/world/asia/indonesia-jakarta-suicidebombings.html.

4 “Attack on North Sumatra Police headquarters kills one officer”, The Jakarta Post, 25 June 2017 available at https://www.thejakartapost.com/news/2017/06/25/attack-on-north-sumatrapolice-headquarters-kills-one-officer.html. 
5 “Island Focus: Cops shot by unknown assailants", The Jakarta Post, 12 September 2017 available at https://www.thejakartapost.com/news/2017/09/12/island-focus-cops-shotunknown-assailants.html.

${ }^{6}$ Kirsten E. Schulze, “The Surabaya Bombings and the Evolution of the Jihadi Threat in Indonesia”, CTC Sentinel, Vol 11, issue 6 (June/July 2018) available at https://ctc.usma.edu/surabaya-bombings-evolution-jihadi-threat-indonesia/. See also IPAC, "The Surabaya Bomings and the Future of ISIS in Indonesia", IPAC Report 51 (October 2018) available at http://www.understandingconflict.org/en/conflict/read/75/The-SurabayaBombings-and-the-Future-of-ISIS-in-Indonesia.

7 "Sidoarjo bomb also involved family of six: E. Java Police", The Jakarta Post, 14 May 2018, available at http://www.thejakartapost.com/news/2018/05/14/sidoarjo-bomb-alsoinvolved-family-of-six-e-java-police.html. "Suicide bombers at Surabaya Police HQ one family", The Jakarta Post, 14 May 2018, available at http://www.thejakartapost.com/news/2018/05/14/suicide-bombers-at-surabaya-policehqone-family.html.

${ }^{8}$ For a comprehensive history of JI see Solahudin, The Roots of Terrorism in Indonesia: From Darul Islam to Jemaah Islamiyah (Canberra, Australia: UNSW Press, 2013). 
${ }^{9}$ For JI in the Poso conflict see David McRae, A Few Poorly Organized Men: Inter-Religious Violence in Poso, Indonesia (Leiden, The Netherlands: Brill/KITLV, 2013) and Muhammad Tito Karnavian, Explaining Islamist Insurgencies: The Case Of Al-Jamaah Al-Islamiyyah and The Radicalisation Of The Poso Conflict, 2000-2007 (London, UK: Imperial College Press Insurgency and Terrorism Series, 2014)

10 Sidney Jones, 'The changing nature of Jemaah Islamiyah', Australian Journal of International Affairs, 59, no. 2 (June 2005), p.173.

${ }^{11}$ Ministry of Home Affairs, The Jemaah Islamiyah Arrests and the Threat of Terrorism: White Paper. (Singapore: Ministry of Home Affairs, 2003), p.8.

12 Joseph Chinyong Liow, “The Mahathir Administration's War against Islamic militancy: operational and ideological challenges", The Australian Journal of International Affairs, 58, no. 2 (June 2004), pp. 245. For a more extensive discussion of Islamism in Malaysia see Joseph Chinyong Liow, Politics and Piety: Islamism in Contemporary Malaysia (Oxford: Oxford University Press 2009). For a more detailed analysis of PAS see Farish A. Noor, Islam embedded: the historical development of the Pan-Malaysian Islamic Party PAS, 19512003 (Kuala Lumpur: Malaysian Sociological Research Institute, 2004).

${ }^{13}$ Liow, “The Mahathir Administration's War against Islamic militancy”, p. 245. ${ }^{14}$ Ibid.

${ }^{15}$ See International Crisis Group, Indonesia: Jihadi Surprise in Aceh, Asia Report No.189 (20 April 2010), available at $<$ https://www.crisisgroup.org/asia/south-eastasia/indonesia/indonesia-jihadi-surprise-aceh>. 
${ }^{16}$ See International Crisis Group, How Indonesian Extremists Regroup, Asia Report No. 228 (19 July 2012), available at < https://www.crisisgroup.org/asia/south-east-asia/indonesia/howindonesian-extremists-regroup>.

${ }^{17}$ Rohan Gunaratna, Inside Al Qaeda: Global Network of Terror (New Delhi, India: Roli Books, 2002), pp. 187, 194.

18 Zachary Abuza, Political Islam and Violence in Indonesia (London and New York: Routledge, 2007), p. 2.

${ }^{19}$ Maria A. Ressa, Seeds of Terror; An Eyewitness Account of Al-Qaeda's Newest Center of Operations in Southeast Asia (New York City, New York: Free Press, 2004), pp. 71, 133, 100.

${ }^{20}$ Ibid., pp. 50, 70.

${ }^{21}$ Ken Conboy, The Second Front: Inside Asia's Most Dangerous Terrorist Network (Jakarta, Indonesia: Equinox Publishing, 2005).

${ }^{22}$ Ibid, p. 75.

${ }^{23}$ Ibid, p. 148.

${ }^{24}$ Ibid.

${ }^{25}$ Ressa, Seeds of Terror, op. cit., p. 68. 
${ }^{26}$ Prashanth Pamareswaran, "Islamic State Eyes Asia Base in 2016 in Philippines, Indonesia: Expert", The Diplomat, 14 January 2016, available at <https://thediplomat.com/2016/01/islamic-state-eyes-asia-base-in-2016-in-philippinesindonesia-expert/>.

${ }^{27}$ Kumar Ramakrishna, “The 'East Asia Wilayah’ of ISIS: Long Time in the Making”, Institute for Autonomy and Governance, 14 October 2017, available at < https://www.rsis.edu.sg/staffpublication/the-east-asia-wilayah-of-isis-a-long-time-in-the-making/> .

${ }^{28}$ Rohan Gunaratna, "Global Threat Forecast 2018”, Counter Terrorist Trends and Analysis 10, no. 1 (January 2018): 2.

${ }^{29}$ Ibid.

${ }^{30}$ See Christoph Reuter, Die Schwarze Macht: Der 'Islamische Staat' und die Strategien des Terrors [The Black Power: The 'Islamic State' and the Strategies of Terror (Munich, Germany: Deutsche Verlagsanstalt, 2015), p. 293; Abdel Bari Atwan, Islamic State: the Digital Caliphate (London, UK: Saqi, 2015), p. 3; Jessica Stern and J.M. Berger, ISIS: The State of Terror (London, UK: William Collins, 2015), p. 181; David Kilcullen, Blood Year: Islamic State and the War on Terror (London, UK: Hurst 2016), p. 3.

${ }^{31}$ John Sidel, Riots, Pogroms, Jihad: Religious Violence in Indonesia (Ithaca, New York: Cornell University Press, 2006), p. xi. 
${ }^{32}$ Solahudin, The Roots of Terrorism in Indonesia, op. cit., p. 24.

${ }^{33}$ Jones, "The Changing Nature of Jemaah Islamiyah", Australian Journal of International Affairs, pp. 169-178; Julie Chernov Hwang, Why Terrorists Quit: The Disengagement of Indonesian Jihadists (Ithaca, New York: Cornell University Press, 2018); Julie Chernov Hwang, "Terrorism in Perspective: An Assessment of Jihad Project Trends", Asia-Pacific Issues \#104 (September 2012); Julie Chernov Hwang, "The Disengagement of Indonesian Jihadists: Understanding the Pathways", Terrorism and Political Violence 29, no. 2 (March 2017): pp. 277-295.

34 Kirsten E. Schulze and Joseph Chinyong Liow, "Making Jihadis, Waging Jihad: Transnational and Local Dimensions of the ISIS Phenomenon in Indonesia and Malaysia", Asian Security, online (February 2018), p. 2, available at <https://www.tandfonline.com/doi/full/10.1080/14799855.2018.1424710>.

35 Natasha Hamilton-Hart, "Terrorism in Southeast Asia: Expert Analysis, Myopia, and Fantasy”, Pacific Review 18, no. 3 (September 2005): 303-325; John Sidel, “The Islamist threat in Southeast Asia: much ado about nothing?", Asian Affairs 16, no. 3 (November 2008); Greg Fealy and Carlyle A. Thayer, "Al-Qaeda in Southeast Asia: Problematising 'linkages' between Regional and International Terrorism", in William Tow (ed.), Re-Envisioning Asia-Pacific Security: A Regional-Global Nexus? (Cambridge, UK: Cambridge University Press, 2009). 